\title{
The interactions among science, politics and communication in a context of crisis
}

\author{
Gabriela Di Giulio \\ Pedro Roberto Jacobi \\ Roberto Silva Jr. \\ Kauê Lopes dos Santos \\ Zenaida Lauda-Rodriguez \\ Beatriz Milz
}

(D) ${ }^{1}$ Deputy Editor of the Journal Ambiente $\mathbb{E}$ Sociedade. Professor of the Department of Environmental Health, Faculty of Public Health (FSP) of the University of São Paulo (USP).

II Chief Editor of the Journal Ambiente $\mathcal{E}$ Sociedade. Full Professor Faculty of Education, University of São Paulo. Professor of the Postgraduate Program in Environmental Science, University of São Paulo.

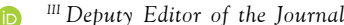
Ambiente $\&$ Sociedade. Professor of the Post-Graduation Program in Environment and Society of the Institute of Philosophy and Human Sciences, of the State University of Campinas (UNICAMP).

(D) Deputy Editor of the Journal Ambiente $\mathcal{E}$ Sociedade. Visiting Researcher of the London School of Economics. Postdoctoral Researcher at the University of the São Paulo.

(1) ${ }^{v}$ Member of the Editorial Executive Secretariat of Journal Ambiente $\mathcal{E}^{\circ}$ Sociedade. PhD in the Post-Graduation Program in Environmental Science, University of São Paulo.

${ }^{\mathrm{V}}$ Member of the Editorial Executive Secretariat of Journal Ambiente $\mathbb{E}$ Sociedade. Doctorate Student in the Post-Graduation Program in Environmental Science, University of São Paulo.
São Paulo. Vol. 23, 2020

Editorial

DOI: http://dx.doi.org/10.1590/1809-4422asoceditorialvu2020L5ED 
Covid-19, climate emergency and environmental degradation are the three crises that characterizes the year of 2020, and certainly will be an important mark of how the 21st-century evidences the force of the consequences of the predatory exploitation model of natural resources, and the current paradigm in recent decades that values economic growth at any cost (SETTELE et al., 2020). These crises, with their synergistic effects, reveal how social inequities and conditions of vulnerability, which persist with greater or lesser intensity in countries around the globe, are reproduced in the intensity of the damage and losses, further widening the abyss between nations, and between social groups. As a result of the interaction between environment and social actions, of processes that unfold over time associated with political, cultural and economic factors, these crises disorganize - such as the pandemic of Covid-19 show in a multidimensional and quite severe way - the routines of our lives. However, its effects can be even more serious if we insist on not promoting urgent, deep and structural socio-political and cultural changes. If we insist on not implementing a sustainability proposal that refers explicitly to issues related to equity, ecological prudence and the guarantee of human rights (LATOUR, 2020; MARQUES, 2020; VENTURA et al., 2020).

These three crises gain even greater reverberation when we situate the effects of other crises that mark the social time we live in: of the institutions, of trust and responsibility (GIDDENS, 1999; BECK, 2010). The intensification of this process comes from a growing recognition that the conditions of production of environmental and epidemiological risks are in cleave with the dynamics of mobility (of information, materialities, people and, as we now perceive drastically, viruses and bacterias) placed in a complex way in the global contexts (URRY, 2007). In the Brazilian context, in particular, these effects are added to the current political polarization and how it is reflected in the dynamics, behaviors and actions of social groups; and the Brazilian political-institutional conjuncture and its reverberations in different dimensions, such as the dismantling of environmental protection structures, protection of public health, and promotion of education, science and technology. These effects are also aligned with discursive frameworks and information flows and how these are impacted by social media and fake news; and the complex interactions between science, politics and society, which involve public trust in science itself and greater or lesser usability of technical and scientific information in decisionmaking processes (SERRAO-NEUMANN et al., 2020; MORGAN; DI GIULIO, 2018).

It is in this combination that, it seems to us, is an important analytical key to understand the scientific, economic and political disputes that mark, to a greater or lesser extent, the institutional responses given so far to these crises in the national context. At the individual level, this analytical key also offers us important clues to understanding adherence to conspiratorial discourses, the willingness to deny facts and evidences, and a more refractory position to a necessary individual and collective protagonism facing these situations.

In this scenario, on the one hand, the Covid-19 pandemic reveals the controversies and disputes at stake, with controversial decisions taken on possible medicines, measures of social isolation, decisions to return activities, restrictions on circulation of people, 
and activities considered non-essential. On the other hand, the few effective actions to minimize the effects of climate change and reverse the worrying picture of environmental degradation shows that the perspective of a vision for the future that aligns scientific evidence, institutional partnerships and commitments for global sustainability have not been echoed on national territory.

There is no doubt that this lack of institutional coordination of actions and the inadequate communication strategies about these crises, their risks and effects can, at the individual level: confuse the population; alleviate concerns to the point of reducing such crises to mere problems by spreading a false sense of security; and foster a fatalistic feeling that the events associated with these crises are provoked by a divine or supernatural force and that they would thus be punishments sent to humankind (DI GIULIO et al., 2017). They may ultimately affect the protection and reaction capacity of individuals. When there is discredit about the knowledge circulating about risks and dangers, when individuals navigate a sea of information (including distorted or incorrect information), amid uncertainties and contradictions, in a context of distrust, where responsibilities are not clearly assumed and shared, that is where the responses that emerge can be quite disastrous at all levels.

Among the many facets that these crises show, we call attention to one that, in our understanding, deserves to be the object of robust reflections: the interactions between science, politics and communication in crisis contexts and how they reverberate in understandings, perceptions, actions and behaviors of individuals. The Covid-19 pandemic, for example, makes it clear that the way in which people understand the risks associated with a new and little-known disease is mediated by the knowledge available, the ways in which this knowledge is accessed, apprehended and interpreted. It is also shaped by the various filters and stations that can amplify or mitigate social concerns about the risks associated with the pandemic, such as the positions of scientists, the narratives circulating through the media, the speeches of government agencies (such as the Ministry of Health, the State and Municipal Health Secretariats), the speeches of politicians who gain greater visibility and the interests of economic groups. It is no wonder that in the international literature about crises and emergencies, there is a consensus that risk communication is a fundamental condition for the adherence of populations to the recommendations of the authorities (in the case of the Covid-19 pandemic, in particular to health authorities) and for greater cohesion between the different public and private actors to give legitimacy to the responses outlined. Such considerations certainly find echoes when we think of the climate crisis and environmental degradation.

Finally, still in this reflection about these interactions, another lesson that these crises pose to us, especially the acute crisis of Covid-19, refers to the process of mutual recognition between science and society, and how this is shaped by communication strategies. It is from this recognition that it is possible, on the one hand, to expand the integration between knowledge and expertise and, on the other hand, to drive a transformation process waving to alternative proposals to the current development model. There is no doubt that this process requires urgent efforts by the scientific community to improve the 
public communication of science, seeking scientific dissemination that favors a reflective, interrogative and problematizing perspective about the scientific knowledge we produce, and the social and cultural conditions and implications of Science and Technology. On the part of Brazilian society, it is necessary to approach universities and research institutions, understanding how these institutions work, what they produce, the impacts of science in people's everyday lives, and the difficulties that exist to continue advancing in the process of knowledge production. In this sense, it may be important to build a renewed effort for a scientific education, so that different social groups are prepared to value, understand and direct their actions and political demands in dialogue with the scientific contents.

In the context of the Covid-19 pandemic, it has became evident that as the complexity of the response and control capacity is made explicit, highlighting our limits, there is an urgent need for new values that mediate our interpersonal relationships and, consequently, the relationships between science, managers and society This requires the continued deconstruction and reconstruction of existing dynamics in the direction of strengthening an agenda of advancement for sustainable practices, in which new dialogues between science and society are built. In this direction, Ambiente \& Sociedade focuses on promoting the production of knowledge that increasingly challenges thought patterns and strengthens spaces guided by knowledge sharing and encouraging dialogue. With this commitment, we present the following Original Articles that are part of this annual volume.

In the study: Image Configuration of Organic Food and its Motivation for Consumption, the authors Deonir De Toni, Gabriel Sperandio Milan, Fabiano Larentis, Luciene Eberle and Aline Weste Procópio sought to identify the configuration of the image of organic foods for their consumers and their motivations for consumption. They showed that the central image of these consumers is formed by attributes that concern products without pesticides, health, natural foods, healthier food and that preserves the environment, strengthening the predominance of a hedonic meaning.

The authors Júlio Augusto de Castro Pellegrini, Elza Maria Neffa Vieira de Castro, Krishna Neffa Vieira de Castro and Mário Luiz Gomes Soares, in the article: Socioenvironmental tensioning in coastal communities: an interdisciplinary study in the mangroves of southern Bahia, demonstrated that interdisciplinary analysis strengthens the debate in different segments of society (companies, environmental agencies, nongovernmental organizations, universities, communities, etc.) and, consequently, tends to favor the transformation of the socio-environmental reality experienced by social groups with less decision-making power.

In the article: Solid waste indicators in local sustainability assessment: a literature review, the authors Natália Molina Cetrulo, Tiago Balieiro Cetrulo, Sylmara Lopes Francelino Gonçalves Dias and Tomás Augusto Barros Ramos showed that $77,8 \%$ of the indicator systems use at most two indicators for Solid Waste, and most of them are dedicated to represent the stages of destination and final disposition of Solid Waste management and environmental aspects of sustainability. They found evidence on the positive impact 
of social participation and recommend including solid waste indicators in these systems.

From the monitoring of the activities of the Regional Trail "Caminho das Araucárias", the analysis of official documents and data on the Brazilian Network of Trails (RBT) present in digital media, the authors Michel Tadeu R. N. de Omena and Michel Bregolin assess the potential contribution of RBT to nature conservation, tourism promotion and wellbeing through outdoor recreation, highlighting its relevance to the conservation of Conservation Units and the generation of employment and local income. In the article: The importance of regional trails for the viability of the Brazilian long trails network.

Seeking to integrate the evolution of regulatory frameworks and the vision of public servers involved in the processes of formulation of standards, the authors Deborah Santos Prado, Luciana Gomes de Araujo, Paula Chamy, Ana Carolina Esteves Dias and Cristiana Simão Seixas, in the article: Social Participation in Management Councils of Protected Areas: Normative advances and the perspective of ICMBio Environmental officers, argues that social participation is formally guaranteed in the standards analyzed; however, paradoxes and challenges related to representativeness, independence, influence and power sharing were identified in decision-making processes.

Alexandre Gori Maia, Cristiane Silva de Carvalho, Leonardo Cesar Venancio and Eduardo Dias Dini, in the article: The motives behind transport mode choice: a study with university students in Brazil, evidences that public transport prevails among lowincome users, mainly due to lack of alternatives; and those who can finance higher costs prefer a private vehicle. The adoption of active transportation remains restricted to a small group of users with positive attitudes towards health and the environment. Finally, they discuss the implications of structural factors, such as infrastructure and public safety, for a sustainable urban transport system.

In the article: Public Policies in the Rural Area of São João del-Rei: An inhabitants' view, the authors Larissa Medeiros Marinho dos Santos, Johnny da Costa Barbosa, Rodrigo Meireles dos Santos and Anna Beatriz Ribeiro Paiva Netto, based on the concepts of Environmental Psychology and the Bioecological Model of Human Development, analyzed interviews based on the life history of eleven participants from six rural communities. The results indicated that the residents see themselves as inhabitants of rural areas, and described the existing public policies, pointing out the needs found in this context.

The authors Carolina Delfante de Pádua Cardoso, Rosa Maria Formiga-Johnsson, Régis Pinto de Lima and Rodrigo de Oliveira Campos, in the article: Monitoring human activities in the Tamoios Ecological Station - Rio de Janeiro: Management challenges, analyze the set of data on tourism, traffic and fishing between 2008 and 2016, through the application of exploratory models of single-stage variance analysis. They conclude that more conciliatory measures are needed to be agreed among stakeholders for traditional activities such as artisanal fishing and other management measures for activities of high incompatibility with the Ecological Station.

Analyzing the experience of mobilization for the withdrawal of the municipality of 
Paragominas/PA from the dirty list of deforestation, and the development of actions to control deforestation in the settlement São Jorge, in the municipality of Cidelândia/MA, the authors Marcelo Sampaio Carneiro, William Santos Assis, Ulisses Denache Vieira Souza and Lidielze Dourado, in the article: Deforestation governance in the Amazon from a Strategic Action Fields perspective, highlighted the relevance of the use of this theory in this context and highlight core concepts such as the performance of skilled social actors and the construction of internal governance units.

In the article: Mercury-Based Mining in Yanomami Indigenous Lands and Accountabilities, based on a bibliographic and documentary survey of a qualitative approach, involving the indigenous Yanomami voice and police, administrative and judicial procedures from 2013 to 2017, the authors Alan Robson Alexandrino Ramos, Keyty Almeida de Oliveira and Francilene dos Santos Rodrigues, show divergences between the protection and responsibilities inscribed in the Brazilian legal order and the clandestine phenomenon studied, which are expressed in violation of indigenous voices, scientific and the ethical imperative.

From the approaches of Biopower in Michel Foucault's Biopolitics and Norman Long's Actor-Oriented Perspective (POA), the authors Michele Laffayett de Campos and Fábio Kessler Dal Soglio highlights experiences of networks of actors that mobilize the conservation of Creole seeds, proving the social and dynamic agency of these networks against global dictates, as opposed to the imposed processes and sociotechnical standards for the use of commercial seeds. In the article: Creole seeds and power relations in agriculture: Interfaces between Biopoder and social agency.

The authors Amanda Borges de Souza, Armando Fornazier and Mauro Eduardo Delgrossi, in the article: Local food systems: potential for new market connections for family farming, seek to identify in the literature the main theories and concepts used in the analysis of "local agrifood systems", verifying the concept of "family farming" in the Brazilian and international academy. The results indicate that these concepts involve topics such as local rural development, consumption politicization, sustainability, market niches, agroecology, land valuation and institutional programs.

In the article: Impacts of the Public Forest Management Law on traditional communities in Crepori National Forest, the authors Natalia Ribas Guerrero, Mauricio Torres and Ítala Nepomuceno evidences that the modalities of protected areas, focused primarily on technological exploitation, are directed at the corporate exploitation of timber resources, to the detriment of the territorial rights of traditional peoples and communities. The results ratify studies in the area that points out the processes of forest concessions as a factor causing negative impacts to traditional communities.

Next, we present our section Ideas in Debate, which brings the article: The Brazilian blue Amazon under threat: why has the oil spill continued for so long? by Leandra R. Gonçalves, DG Webster, Oran Young, Marcus Polette and Alexander Turra. The authors address the oil spill incident that occurred in August 2019, which hit the coast of Brazil, affecting some of the country's most preserved beaches. They conclude that although 
Brazil has emerged as an environmental leader in the international arena in the past, it has left much to be desired in the actions needed to prevent spills like this from affecting other coastal communities and biodiversity.

Finally, we conclude this editorial with our Reviews section. On this occasion, Carlos Alberto Seifert Jr., Guilherme de Queiroz Stein and Alfredo Alejandro Gugliano present the book: Between Polis and Physis: Democracy as a problem and a solution for the climate crisis, by Frank Fischer, who, according to the authors, taking on the inevitability of the crisis, part for the political debate on the "place of democracy" in an established context of global disaster. From this, the author of the book addresses the structures and mechanisms of democratic resistance, bringing to the discussion perspectives eco-localists. The authors analyze the potentialities and weaknesses of Fischer's arguments, which become a fundamental reference to the theme.

\section{We wish you all a good reading!}

\section{References}

BECK, U. Sociedade de risco rumo a uma outra modernidade. 2. ed. São Paulo, Editora. 34, 2010.

DI GIULIO, G. M.; VIGLIO, J. E.; FERREIRA, L. C. Alterações climáticas, riscos e percepções: Análise sobre uma região costeira do Brasil. In: FERREIRA, L. C. et al. (Orgs.). Clima de tensão: Ação humana, biodiversidade e mudanças climáticas. 1ed. Campinas: Editora Unicamp,v. 1, p. 293-308, 2017.

GIDDENS, A. Risk and responsibility. Modern Law Review, Hoboken, v. 62, n.1, p. 1-10, 1999.

LATOUR, B. A crise sanitária incentiva a nos prepararmos para as mudanças climáticas, Le Monde, 25 de mar. de 2020. Disponível em: < http://agbcampinas.com.br/site/2020/bruno-latour-a-crise-sanitaria-incentiva-a-nos-prepararmos-para-as-mudancas-climaticas/?fbclid=IwA ROzhkHTnTjrjzGMPQ96u3N7nDzebWWGxNxAwrcsAzEcWXrOCC8HU3vqlqM>. Acesso em: 13 maio 2020.

MARQUES, L. A pandemia incide no ano mais importante da história da humanidade. Serão as próximas zoonoses gestadas no Brasil? Ciência, Saúde e Sociedade: Covid-19. Unicamp, 2020. Disponível em: < https:/www.unicamp.br/unicamp/noticias/2020/05/05/pandemia-incide-no-ano-mais-importante-da-historia-da-humanidade-serao-proximas >. Acesso em 14 maio 2020.

MORGAN, E. A.; DI GIULIO, G. M. Science and Evidence-Based Climate Change Policy: Collaborative Approaches to Improve the Science? Policy Interface. In: SERRAO-NEUMANN, S.; COUDRAIN, A.; COULTER, L. (Orgs.) Communicating Climate Change Information for Decision-Making. 1ed.: Springer International Publishing, v., p. 13-28, 2018.

SERRAO-NEUMANN, S; DI GIULIO, G.; LOW CHOY, D. When salient science is not enough 
to advance climate change adaptation: Lessons from Brazil and Australia. Environmental Science $\&$ Policy, v. 109, p. 73-82, 2020.

SETTELE, J.; DÍAZ, S.; BRONDIZIO, E. COVID-19 - Stimulus Measures Must Save Lives, Protect Livelihoods, and Safeguard Nature to Reduce the Risk of Future Pandemics. Ipbes, 2020. Disponível em < https://ipbes.net/covid19stimulus>. Acesso em: 13 maio 2020.

URRY, J. Mobilities. Cambridge, UK: Polity, 2007.

VENTURA, D. de F. L.; DI GIULIO, G. M.; RACHED, D. H. Lessons from the Covid-19 pandemic: sustainability is an indispensable condition of Global Health Security. Ambiente $\mathbb{\&}$ Sociedade (Online), v. 23, p. 1-11, 2020. 


\section{Gabriela Di Giulio}

๑ggiulio@usp.br

ORCiD: https://orcid.org/0000-0003-1396-9788

\section{Pedro Roberto Jacobi}

$\square$ prjacobi@gmail.com

ORCiD: https://orcid.org/0000-0001-6143-3019

\section{Roberto Silva Jr.}

$\square$ roberto.junior@fca.unicamp.br

ORCiD: https://orcid.org/0000-0002-9101-7048

\section{Kauê Lopes dos Santos}

$\square$ kauegeo@gmail.com

ORCiD: https://orcid.org/0000-0001-9996-1079

\section{Zenaida Lauda-Rodriguez}

$\square$ zeni.lauda.rodriguez@gmail.com

ORCiD: https://orcid.org/0000-0003-2432-0255

\section{Beatriz Milz}

$\square$ beatriz.milz@usp.br

ORCiD: https://orcid.org/0000-0002-3064-4486

How to cite: DI GIULIO, G. M. et al. Editorial 05/2020 - The interactions among science, politics and communication in a context of crisis. Ambiente $\mathbb{E}$ Sociedade. São Paulo, v. 23, p. 1-9, 2020. 